\title{
Synaptic Integration of Adult-Generated Olfactory Bulb Granule Cells: Basal Axodendritic Centrifugal Input Precedes Apical Dendrodendritic Local Circuits
}

\author{
Mary C. Whitman ${ }^{1}$ and Charles A. Greer ${ }^{1,2}$ \\ Departments of ${ }^{1}$ Neurobiology and ${ }^{1}$ Neurosurgery, Yale University School of Medicine, New Haven, Connecticut 06520-8082
}

\begin{abstract}
The adult mammalian olfactory bulb $(\mathrm{OB})$ receives a continuing influx of new interneurons. Neuroblasts from the subventricular zone (SVZ) migrate into the $\mathrm{OB}$ and differentiate into granule cells and periglomerular cells that are presumed to integrate into the synaptic circuits of the OB. We have used retroviral infection into the SVZ of mice to label adult-generated granule cells and follow their differentiation and integration into $\mathrm{OB}$ circuitry. Using synaptic markers and electron microscopy, we show new granule cells integrating into the reciprocal circuitry of the external plexiform layer (EPL), beginning at $21 \mathrm{~d}$ postinfection (dpi). We further show that synapses are formed earlier, beginning at $10 \mathrm{dpi}$, on the somata and basal dendrites of new cells in the granule cell layer (GCL), before dendritic elaboration in the EPL. In the EPL, elaborate dendritic arbors with spines are first evident at $14 \mathrm{dpi}$. The density of spines increases from 14 to $28 \mathrm{dpi}$, and then decreases by $56 \mathrm{dpi}$. Despite the initial appearance of dendritic spines at $14 \mathrm{dpi}$ in the EPL, no expression of presynaptic or postsynaptic markers is seen until $21 \mathrm{dpi}$. These data suggest that adult-generated granule cells are first innervated by centrifugal or mitral/tufted cell axon collaterals in the GCL and that these inputs may contribute to their differentiation, maturation, and synaptic integration into the dendrodendritic local circuits found in the EPL.
\end{abstract}

Key words: neurogenesis; synaptogenesis; dendrite; spine; cholinergic; rostral migratory stream

\section{Introduction}

Ongoing neurogenesis contributes new interneurons to the adult olfactory bulb $(\mathrm{OB})$ and dentate gyrus (for review, see Lledo et al., 2006). In the dentate, granule cells generated in the subgranular zone migrate into the overlying granule cell layer and integrate into existing synaptic circuits (Ming and Song, 2005; Ge et al., 2006; Zhao et al., 2006). New OB cells are generated in the subventricular zone (SVZ) and migrate several millimeters through the rostral migratory stream (RMS) to the OB where they differentiate into granule cells and periglomerular (PG) cells (Whitman and Greer, 2007).

Differentiation and maturation of adult-generated OB granule cells occurs in five stages (Petreanu and Alvarez-Buylla, 2002). Cells in stages 1 and 2 (days 2-7 postretroviral infection) are migratory, with a prominent leading process and a small trailing process. Stage 3 cells (days 9-13) reach the granule cell layer (GCL) and have a simple dendrite extending toward, but not past, the mitral cell layer. Stage 4 cells (days 11-22) have extensive

\section{Received April 11, 2007; revised July 27, 2007; accepted July 30, 2007.}

This work was supported by National Institutes of Health Grants DC00210, DC006972, DC006291, and AG028054 (C.A.G.). M.C.W. was supported by Yale Medical Scientist Training Program Grant GM07205. We thank Dolores Montoya and Christine Kaliszewski for technical assistance, Drs. Diego Rodriguez Gil, Fumiaki Imamura, Lorena Rela, and Helen Treloar for critical reading of this manuscript, and all members of the laboratory for ongoing discussions and advice. We also thank Drs. Pierre-Marie Lledo and Mariana Alonso of the Pasteur Institute (Paris, France) for encouragement and advice.

Correspondence should be addressed to Dr. Charles A. Greer, Department of Neurosurgery, Yale University School of Medicine, P.0. Box 208082, New Haven, CT 06520-8082. E-mail: charles.greer@yale.edu.

DOI:10.1523/JNEUROSCI.1633-07.2007

Copyright $\odot 2007$ Society for Neuroscience $\quad$ 0270-6474/07/279951-11\$15.00/0 dendritic arbors without spines. Stage 5 cells (days 15-30) have mature morphologies with spiny dendrites. Between 15 and $45 \mathrm{~d}$ after generation, $50 \%$ of adult-generated granule cells die (Petreanu and Alvarez-Buylla, 2002), perhaps reflecting their failure to integrate into synaptic circuits.

The membrane properties of adult-generated cells with mature morphology are indistinguishable from those of older cells (Carleton et al., 2003). Odor stimulation increases survival in newborn granule cells (Rochefort et al., 2002; Magavi et al., 2005; Alonso et al., 2006), whereas deprivation appears to decrease differentiation and survival (Saghatelyan et al., 2005; Yamaguchi and Mori, 2005).

Evidence for the formation of synapses by adult-generated $\mathrm{OB}$ cells has been elusive. Carlen et al. (2002) reported transsynaptic transport of pseudorabies virus from mitral cells into adultgenerated PG cells. Similarly, PG cells beginning at $24 \mathrm{~d}$ appear apposed to synapsin ${ }^{+}$puncta and exhibit diffuse colocalization of synaptic vesicle protein 2 (Belluzzi et al., 2003). Synaptophysin puncta appear proximal to the somata and basal dendrite of adult-generated granule cells, but evidence for their integration into functional external plexiform layer (EPL) synaptic circuits remains inconclusive (Magavi et al., 2005). In addition to their dendrodendritic circuits in the EPL, granule cells also receive centrifugal synapses onto their somata and basal dendrites in the GCL (Shepherd et al., 2004), but these have not been addressed in the context of adult neurogenesis.

We present evidence that adult-generated granule cells are fully integrated into OB synaptic circuits. Significantly, we show 
that new granule cells first receive synapses on their cell bodies and basal dendrites, considerably before synapse formation on their apical dendrites. We also demonstrate that granule cell dendritic spines can form bidirectional dendrodendritic synapses, beginning at $21 \mathrm{~d}$ postinfection (dpi) and that the stabilization of the EPL circuits parallels a transient hypertrophy of spines. The precocious formation of synapses onto the basal compartments of the newborn granule cells suggests a more important role of centrifugal and mitral cell axon collaterals in the differentiation and stabilization of adult-generated cells than hypothesized previously.

\section{Materials and Methods \\ Animals}

For retroviral injection, $\sim 1 \mu \mathrm{l}$ of concentrated retrovirus $\left(10^{8} \mathrm{cfu} / \mathrm{ml}\right)$ encoding tau green fluorescent protein (tauGFP; a kind gift from Drs. A. Chesler and S. Firestein, Columbia University, New York, NY) was injected in 6- to 9-week-old male C57BL/6 mice (Charles River Laboratories, Wilmington, MA) at the following coordinates (in millimeters) relative to bregma: anterior, 0.0; lateral, \pm 1.0 ; depth, 2.2. The retrovirus, derived from Moloney murine leukemia virus, infects only dividing cells and is replication incompetent (Chesler et al., 2007). After recovery, animals were housed singly with a $12 \mathrm{~h}$ light/dark cycle and access to food and water ad libitum. All animal care and use was approved by the Yale University Animal Care and Use Committee.

Mice were anesthetized with pentobarbital and perfused transcardially with PBS with $1 \mathrm{U} / \mathrm{ml}$ heparin, followed by $4 \%$ paraformaldehyde. The brain was removed from the skull and postfixed in the same fixative for $2 \mathrm{~h}$. Brains were rinsed in PBS overnight, cryopreserved in $30 \%$ sucrose in PBS and cut on a sliding-freezing microtome $(50 \mu \mathrm{m})$, and stored at $-20^{\circ} \mathrm{C}$ until use.

For electron microscopy, the mice were perfused with $4 \%$ paraformaldehyde and $0.1 \%$ or $0.5 \%$ glutaraldehyde, followed by postfixation in the same fixative for $4 \mathrm{~h}$. Brains were rinsed in PBS overnight and cut on a vibratome $(50 \mu \mathrm{m})$.

\section{Immunohistochemistry}

Confocal microscopy. Tissue was washed out of antifreeze solution with PBS with $0.3 \%$ Triton-X (PBS-T), blocked with $2 \%$ BSA in PBS-T (blocking buffer) at RT for 20-60 min and incubated with primary antibodies diluted in blocking buffer at $4^{\circ} \mathrm{C}$ overnight. Sections were washed with PBS-T, then incubated in secondary antibodies and DRAQ5 (nuclear marker; Alexis Biochemicals, San Diego, CA) for $2 \mathrm{~h}$ at room temperature, washed in PBS-T, and then PBS. To reduce autoflourescence from lipofuscin granules, sections were stained with $1 \%$ Sudan black in 70\% methanol for $5 \mathrm{~min}$, cleared in 70\% ethanol, and rinsed in PBS (Schnell et al., 1999) before mounting in Prolong Gold (Invitrogen, Carlsbad, CA) or GelMount (Bioveda, Foster City, CA). For anti-choline acetyltransferase (ChAT), biotinylated secondary antibody was used, followed by the Vector (Burlingame, CA) Elite ABC reagent and biotinylated tyramide signal amplification (PerkinElmer, Wellesley, MA), and then flourophore conjugated streptavidin.

Electron microscopy. Vibratome sections were blocked in 2\% BSA at room temperature for 30-90 min and incubated with primary antibody overnight at $4^{\circ} \mathrm{C}$. Biotinylated secondary antibody was followed by the $\mathrm{ABC}$ reagent (Vector) and a DAB peroxidase reaction. Tissue was then counterstained with osmium tetroxide and embedded for thin sectioning in acrylite. Sections of $100 \mathrm{~nm}$ were examined on a Phillips transmission electron microscope and photographed at $10,000-12,000 \times$ primary magnifications.

\section{Primary antibodies and concentrations}

Primary antibodies and concentrations used were as follows: rabbit antiGFP (1:1000; Invitrogen); mouse anti-GFP (1:1000; Invitrogen); rabbit anti-synaptoporin (1:2000; Synaptic Systems, Goettingen, Germany); rabbit anti-GluR2/3 (1:100; Millipore, Temecula, CA); rabbit antiPSD-95 (1:1000; Invitrogen); goat anti-ChAT (1:100; Millipore); mouse anti-gephyrin (1:2000; Synaptic Systems); mouse anti-bassoon (1:2000;
Synaptic Systems); and rabbit anti-GABA $A_{\mathrm{A}} \alpha 1$ (1:100; Alomone Labs, Jerusalem, Israel).

\section{Secondary antibodies and concentrations}

Secondary antibodies and concentrations used were as follows: donkey anti-mouse-Alexa 488 (1:1000; Invitrogen); donkey anti-rabbit-Alexa 488 (1:1000; Invitrogen); donkey anti-mouse-Alexa 555 (1:1000; Invitrogen); donkey anti-rabbit-Alexa 555 (1:1000; Invitrogen); donkey antirabbit-biotin (1:1000; Jackson ImmunoResearch, West Grove, PA); and horse anti-goat-biotin (1:1000; Vector).

\section{Image acquisition and analysis}

Images were acquired with a Leica (Wetzlar, Germany) confocal microscope, using $40 \times$ or $63 \times$ oil-immersion objectives, and up to $3.24 \times$ digital zoom. $Z$-stacks were taken through the area of interest, with 0.12 $0.5 \mu \mathrm{m}$ steps between images. Unless otherwise indicated, images displayed are the maximum projections, generated with Leica confocal software. Levels were adjusted in Adobe (San Jose, CA) Photoshop, but the images were otherwise unaltered.

Spine density was measured on distal dendritic segments using maximum projections of high magnification images. Dendrite length was measured by drawing a line along the dendrite and measuring the length of the line, using MetaMorph software. The number of spines along that length was manually counted, and divided by the length to get a measure of density. For each time point, between 37 and 60 individual dendritic lengths were measured, from a minimum of three animals. One-way ANOVA, followed by Bonferroni's multiple comparison test, was used to test for statistical significance.

Spine morphology was measured on distal dendritic segments using maximum projections of high magnification images. Each process was rated as either filopodial or pedunculated, based on the presence of a well defined spine head. Results are presented as the percentage of processes that are filopodial. For each time point, between 10 and 20 individual dendritic lengths were counted, from a minimum of three animals. Oneway ANOVA, followed by Bonferroni's multiple comparison test, was used to test for statistical significance.

\section{Results \\ Morphology}

To investigate the maturation and synaptic integration of adultgenerated granule cells, we used a retroviral labeling method. Retrovirus encoding tauGFP was injected into the lateral ventricle of young adult mice. The retrovirus infects only dividing cells, so all cells labeled were dividing in the SVZ at the time of injection. Because the timeframe of infection and migration may be variable, throughout our analyses we focused on those cells that exhibited the most mature morphology. The tauGFP construct ensured that the GFP label distributes throughout the extent of the cell, including the dendritic spines (Whitman and Greer, 2007). Ten days after viral injection (Fig. 1A), cells were seen in the GCL, extending an apical dendrite toward the EPL. This dendrite did not extend significantly into or branch within the EPL. Because it was also devoid of spine-like protrusions, it appears most similar to the stage 3 cells described by Petreanu and Alvarez-Buylla (2002). At this time, 10 dpi, many GFP-positive cells are present within the RMS (data not shown); the most mature cells within the GCL extended only a short apical dendrite and several basal dendrites. However, $4 \mathrm{~d}$ later, at $14 \mathrm{dpi}$, some cells appeared quite mature (Fig. $1 B$ ). These cells extended an apical dendrite into the EPL, where it usually branched into several secondary and tertiary branches that included spine-like protrusions. Basal dendrites within the GCL were also spiny. These were the most mature cells seen at this time point; many labeled cells were still within the RMS and had a migratory phenotype (data not shown). After the rapid changes seen between 10 and 14 dpi, adult-generated cells have a grossly similar morphology from 21 to 56 dpi (Fig. $1 C-E$ ), with one long apical dendrite that 

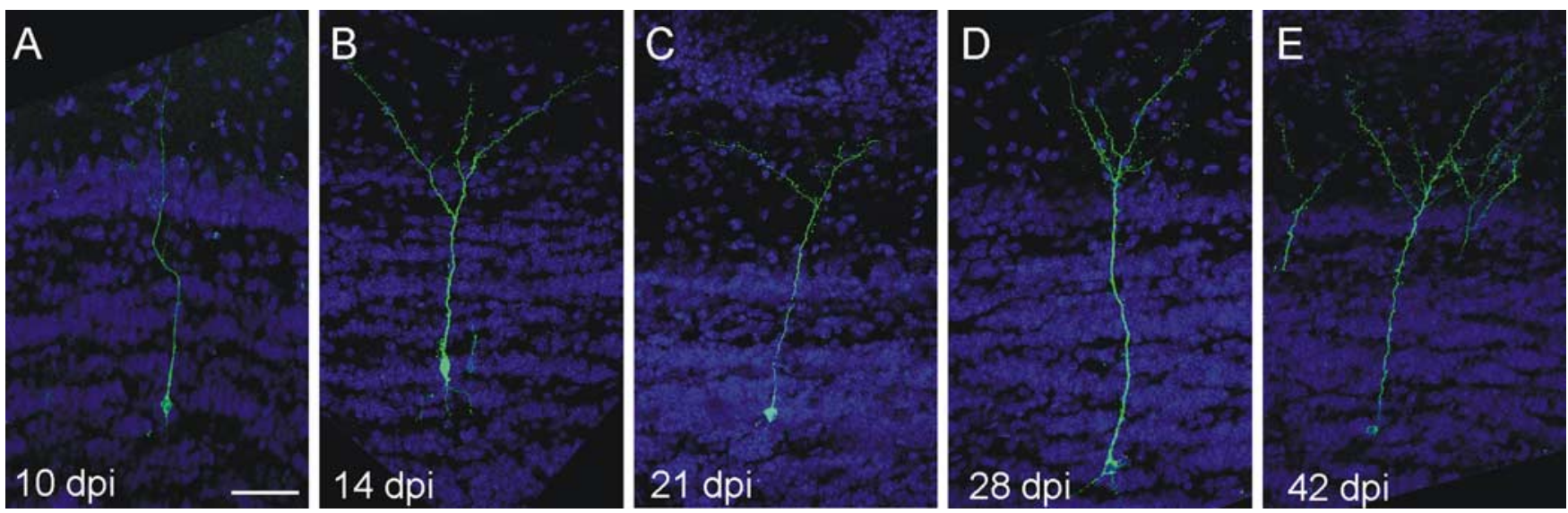

Figure 1. Maturation of adult-generated granule cells. $A$, Ten days after viral labeling in the SVZ, cells have migrated into the GCL, and extended an apical dendrite toward the EPL. $\boldsymbol{B}$, By 14 dpi, the apical dendrites have developed considerably, with several branches in the EPL, as well as spines along the dendrites. $(-\boldsymbol{E}$, The basal dendrites have also developed spines. At $21 \mathrm{dpi}(\boldsymbol{C}), 28 \mathrm{dpi}$ $(\boldsymbol{D})$, and $42 \mathrm{dpi}(\boldsymbol{E})$, cells look remarkably similar, with one long apical dendrite with three to four branches in the EPL, and several short basal dendrites. All images are maximum projections of confocal stacks through the full thickness of the cell. Green is GFP, and blue is DRA05, a nuclear marker. Scale bar: (in $A) A-E, 50 \mu \mathrm{m}$.

branches in the EPL, and several short basal dendrites around the cell body. Of note, we rarely saw cells with extensive dendritic arbors and no spines (stage 4), the vast majority of dendrites had spines, indicating that spine formation proceeds quickly after dendritic growth.

At higher magnification, the continual development of adultgenerated cells is evident. There is a significant change in the density of spine-like processes along the dendrite at different survival times $(F=6.299 ; p \leq 0.0007$, ANOVA). At 14 dpi, dendrites in the EPL have spines, although at low density (Fig. $2 A, F)$. Almost half ( $46.5 \pm 6.5 \%)$ of the spines are thin, filopodia-like, or possibly protodendritic branch points, the remaining are pedunculated with well defined heads. By $21 \mathrm{dpi}$, spines are more densely packed along the dendrite (Fig. $2 B, F$ ) and the majority of spines appear more mature, with well delineated necks and heads $(27.5 \pm 3.8 \%$ filopodial). The spine density increases further at 28 dpi (Fig. 2C,F), then remains steady to 42 dpi (Fig. $2 D, F$ ). Often, two spines seem to arise from the same point on the dendrite, heading in opposite directions. Most of the spines at $28 \mathrm{dpi}$ and $42 \mathrm{dpi}$ are mature pedunculated spines, but there continue to be filopodial spines interspersed $(26.1 \pm 3.6 \%$ filopodial at $28 \mathrm{dpi}$; $28.9 \pm 2.6 \%$ at $42 \mathrm{dpi}$ ). The developmental transition from filopodia-like protrusions to well defined pedunculated spines is similar for adult-generated granule cells in the dentate gyrus, suggesting that some aspects of spinogenesis and synapse formation may be conserved (Toni et al., 2007). Unexpectedly, as the olfactory granule cells continue to mature to $56 \mathrm{dpi}$, the density of spines along the dendrites decreases (Fig. $2 E, F$ ). The appearance of the spines is similar to earlier ages, with $24.4 \pm 3.8 \%$ filopodial, but there are fewer along the dendrite. This is especially interesting because $\sim 50 \%$ of adult-generated granule cells die $15-45 \mathrm{~d}$ after generation; the remaining cells can survive for long periods of time (Petreanu and Alvarez-Buylla, 2002). Therefore, cells at 56 dpi have survived the initial massive die-off and presumably will survive long-term. The decrease in spine density in these surviving cells may therefore reflect an overproduction and then pruning of synaptic contacts, similar to that seen in many brain regions during development. Thus, there is both an overproduction of new cells, with many being lost, and of spines, with subsequent pruning to refine contacts. At all time points there is some variability on dendrites, with some areas, even along the same dendrite, having very dense spines whereas other areas are relatively sparse. Within the EPL, there is a tendency for the distal end of a dendritic branch to have the densest distribution of spines, whereas the more proximal portion has fewer spines.

\section{Synapse formation}

The presence of dendritic spines has often been used as a priori evidence for the presence of synaptic connections (Miller and Peters, 1981; Mates and Lund, 1983). However, previous studies suggest that the initial extension of spine-like processes may be highly dynamic and may precede synapse formation (Knott et al., 2006; Alvarez and Sabatini, 2007). Therefore, after examining the development of spines on adult-generated cells, we next asked whether these spines make and receive synapses.

Granule cells of the $\mathrm{OB}$ are unique in their patterns of connectivity. They are anaxonic interneurons. They form reciprocal dendrodendritic synapses in the EPL with the lateral dendrites of mitral and tufted cells. They also receive axodendritic and axosomatic synapse input on their basal dendrites and somata, respectively, from centrifugal fibers, mitral cell axon collaterals, and axon collaterals from tufted and external tufted cells (Shepherd et al., 2004). Because granule cells modulate the activity of the mitral and tufted cells via GABA released from their spines within the EPL, we first examined labeled dendrites in the EPL for evidence of presynaptic specializations, specifically synaptic vesicle proteins. Antibodies to synaptoporin, a vesicle membrane protein also known as synaptophysin 2, localize specifically to granule cell spines in the EPL; they stain EPL in a punctuate manner, reflecting the large number of synapses (Fig. 3A) (our unpublished observations). We first found evidence of synaptoporin puncta in the EPL colocalizing with GFP labeled dendritic spines at 21 dpi (Fig. $3 A$ ), when $52.6 \pm 4.6 \%$ of spines colocalize. By 42 $\mathrm{dpi}$, the colocalization of GFP and synaptoporin has increased to $62.7 \pm 6.8 \%$ of spines (Fig. $3 B$ ). The presence of synaptoporin is consistent with the conclusion that the adult-generated granule cells are synapsing onto the lateral dendrites of mitral and tufted cells by $21 \mathrm{dpi}$ and that the number of spines making synapses continues to increase through at least $42 \mathrm{dpi}$.

The presence of a presynaptic marker, although promising, did not confirm the formation of a synapse. To pursue the question further, we labeled for gephyrin, a protein associated with clustering of GABA and glycine receptors and, thus, a postsynaptic marker of GABAergic synapses in the EPL dendrodendritic 

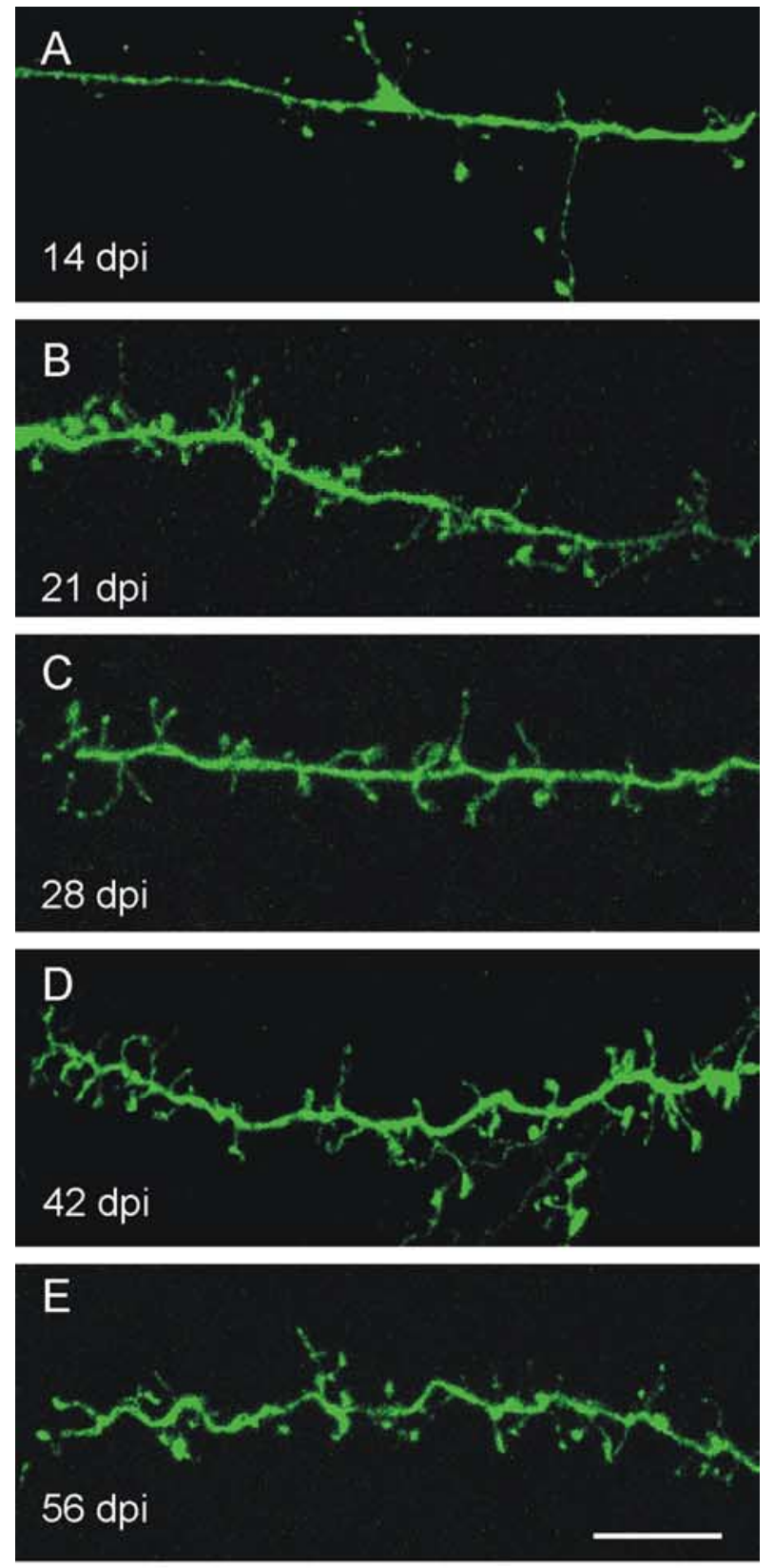

\section{F Spine Density}

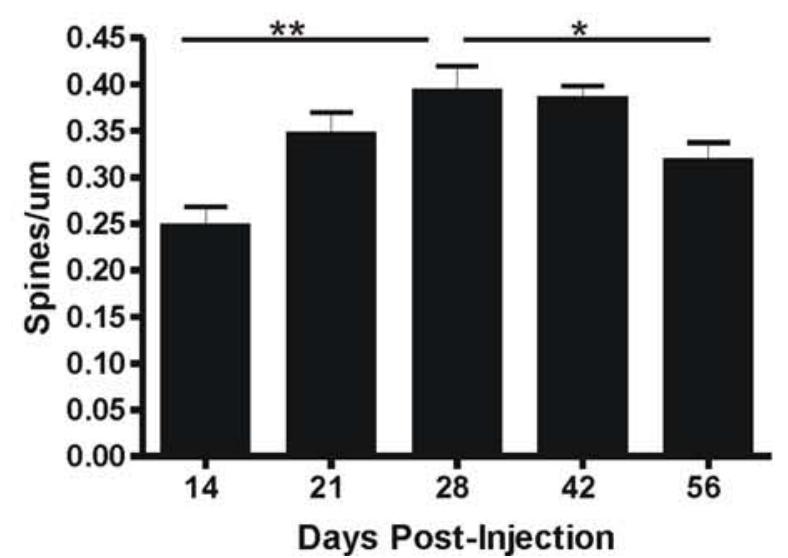

Figure 2. Spine density increases and then decreases as the cells mature. $A$, Fourteen days after viral labeling in the SVZ, dendrites in the EPL have spines, but at a low density along the shaft. $\boldsymbol{B}$, Spine density increases by $21 \mathrm{dpi}$, as does the apparent maturity of the spines (more circuits (Sassoe-Pognetto and Fritschy, 2000; Isaacson and Vitten, 2003). Gephyrin is therefore expressed predominately by mitral and tufted cell dendrites; rare examples of gephyrin puncta can occur in granule cells as well, most likely because of the occasional symmetric synapses on their dendritic shafts (Price and Powell, 1970). In the EPL, gephyrin puncta are densely distributed and are often aligned in rows that correspond to longitudinally cut mitral or tufted cell lateral dendrites (data not shown). If synapses are formed on adult-generated granule cells, we predicted that gephyrin puncta should be closely apposed to GFP labeled spines, but should not colocalize within the spines. Indeed, that is what we found, starting at $21 \mathrm{dpi}$. As shown in Figure 4 , gephyrin puncta can be readily seen in close apposition to labeled spines, but there was no evidence for coexpression of gephyrin and GFP. Similar to the results for synaptoporin, at 21 dpi, $53.2 \pm 2.0 \%$ of spines are apposed to a gephryin puncta, with a slight increase at $42 \mathrm{dpi}$ to $62.8 \pm 2.9 \%$ spines apposed. These results are consistent with the notion that beginning around 21 $\mathrm{dpi}$, adult-generated granule cells develop presynaptic specializations that are closely apposed to mitral and tufted cell dendrites within the EPL and that their frequency increases as the cells age.

To confirm the timing of synapse formation and exclude the possibility that synaptoporin and gephyrin were particularly late markers of adult-generated granule cell synapses, we used two additional markers. Bassoon, a presynaptic marker, is a large $\mathrm{Zn}^{2+}$ finger protein that forms the scaffolding of the presynapse, and may also be involved in synaptic vesicle cycling (tom Dieck et al., 1998). Antibodies to bassoon also stain the EPL in a punctuate manner. We first observed colocalization between GFP labeled spines and bassoon at $21 \mathrm{dpi}$ (supplemental Fig. 1, available at www.jneurosci.org as supplemental material). As an additional postsynaptic marker, we used the $\alpha 1$ subunit of the $\mathrm{GABA}_{\mathrm{A}}$ receptor, which is specific to mitral and tufted cells (Panzanelli et al., 2005). Again, we first saw apposed puncta at 21 dpi (supplemental Fig. 2, available at www.jneurosci.org as supplemental material).

As noted above, the reciprocal dendrodendritic local circuit of the EPL includes the inhibitory granule to mitral/tufted cell synapse and the excitatory mitral/tufted to granule cell synapse. The data presented above demonstrated the emergence of presynaptic specializations in the granule cells at $21 \mathrm{dpi}$. To determine whether the reciprocal circuit formed, we next asked whether adult-generated granule cells also developed postsynaptic specializations to receive synaptic input at their apical dendrites in the EPL. Because glutamate is released at the mitral cell dendritic synapses, as a postsynaptic marker we used an antibody to the GluR2 and GluR3 subunits of the AMPA receptor (Isaacson and Strowbridge, 1998). Previous ultrastructural work has shown that the GluR2/3 subunits are located in the postsynaptic density in established synaptic circuits in the rat EPL and rat retina (Sassoe-Pognetto and Ottersen, 2000; Zhang and Diamond, 2006). In the EPL, puncta immunoreactive for GluR2/3 were heavily distributed. Colocalization with GFP labeled cells, however, was first seen at $21 \mathrm{dpi}$ in both dendritic spines and, to a lesser extent, in dendritic shafts (Fig. 5). Thus, the appearance of the postsynaptic glutamate receptor in the adult-generated gran-

pedunculated, less filopodial). $\boldsymbol{C}-\boldsymbol{E}$, At $28 \mathrm{dpi}(\boldsymbol{C})$ and $42 \mathrm{dpi}(\boldsymbol{D})$, spines are very dense along the dendrite, but spine density decreases by $56 \mathrm{dpi}(\boldsymbol{E})$. Quantification is shown in $\boldsymbol{F}$. One-way ANOVA, $p \leq 0.0007$, followed by Bonferroni's multiple comparison test; ${ }^{*} p \leq 0.05$; ${ }^{* *} p \leq$ 0.001. Scale bar: (in $\boldsymbol{E}) \boldsymbol{A}-\boldsymbol{E}, 10 \mu \mathrm{m}$. Error bars indicate SEM. 

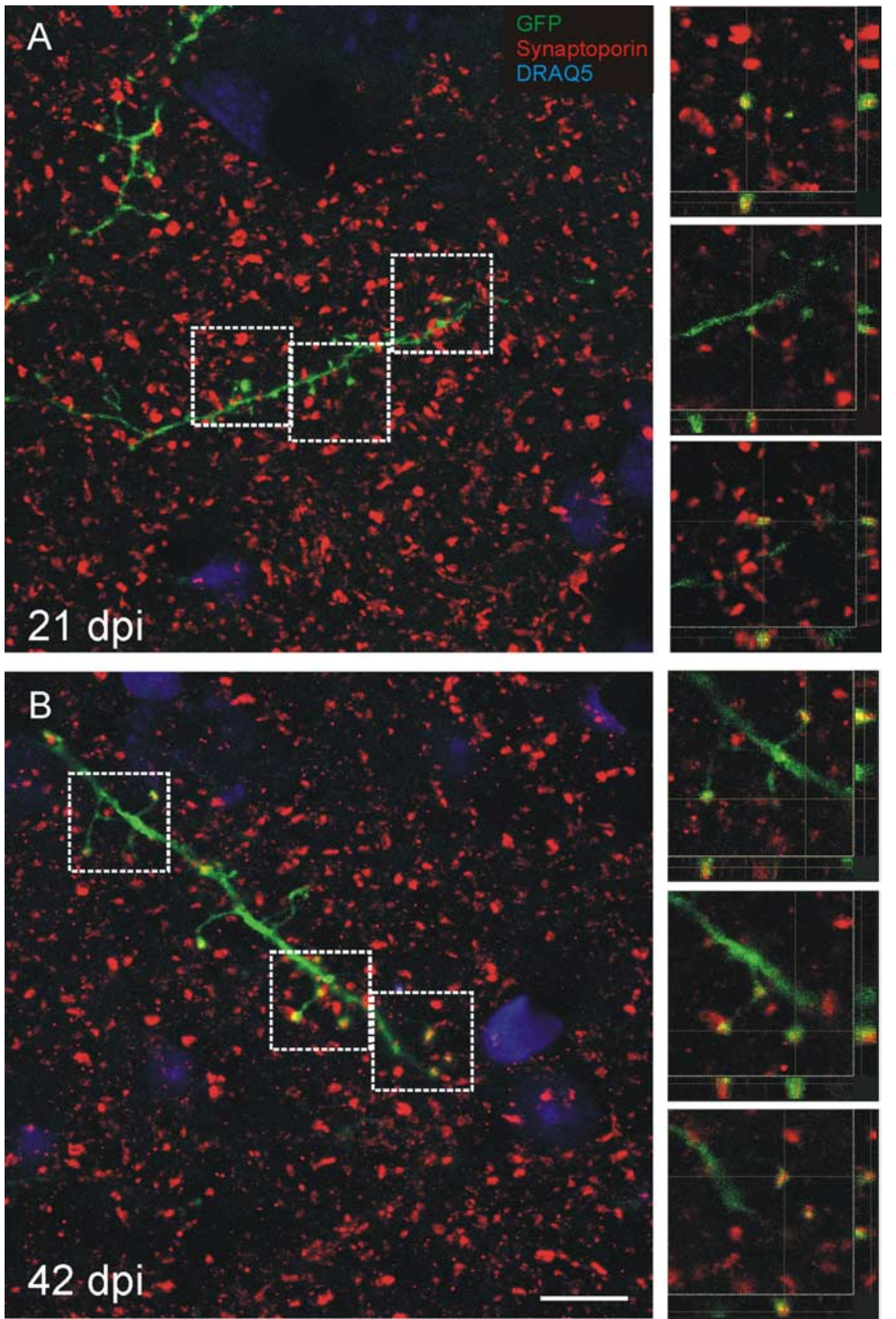

Figure 3. Adult-generated cells express synaptoporin, a presynaptic marker of granule cells. $A$, Synaptoporin (red) puncta in the EPL first colocalize with spine heads on labeled cells (green) at $21 \mathrm{dpi}$. B, By $42 \mathrm{dpi}$, the colocalization of GFP and synaptoporin is evident throughout the EPL and repeatedly along the same dendritic process. Images on the left are maximum projections of confocal images, and images on the right are higher-magnification single optical planes, of the boxed areas on the left, showing the $z$ dimension. Scale bar: (in $\boldsymbol{B}) \boldsymbol{A}, \boldsymbol{B}, 10 \mu \mathrm{m}$.

ule cell spines coincides with the appearance of presynaptic markers. The percentage of spines that express the postsynaptic marker GluR2/3 $(52.8 \pm 1.4 \%$ at $21 \mathrm{dpi})$ is also similar to the percentage expressing the presynaptic marker synaptoporin. The symmetric and asymmetric synapses of the reciprocal dendrodendritic circuits are thus formed within the same temporal window, beginning $\sim 21 \mathrm{~d}$ postinfection. Our data do not allow us to address at this time the possibility that the asymmetric glutamatergic synapse forms first, followed by the symmetric GABAergic synapse (Hinds and Hinds, 1976a,b).

Given the challenge of demonstrating the presence of gluta- matergic receptors with immunohistochemistry, and to confirm the presence of synapses on adult-generated cells, we next used electron microscopy to examine the ultrastructure of GFP labeled granule cells. We reasoned that showing the absence of a synapse, at the earliest ages when the immunohistochemistry had indicated the lack of synapse-related proteins, would not be a particularly effective goal to pursue. In lieu of this, we asked whether in adult-generated granule cells there was evidence for the formation of the classic reciprocal dendrodendritic synapse in the EPL. We chose 42 dpi for the ultrastructural analyses, because at this time there is a high density of spines expressing synaptic markers and, thus, an increased probability of finding labeled spines and synapses. Virally labeled cells were marked by GFP immunohistochemistry and DAB to form an electron dense product, so spines of adult-generated granule cells are electron dense.

In unlabeled tissue processed conventionally, reciprocal dendrodendritic synapses in the EPL present a classic appearance (Fig. 6A). The mitral cell secondary dendrite, cut either longitudinally or transversely, has a collection of small spherical vesicles closely apposed to the presynaptic membrane. Apposed to the mitral cell specialization is an asymmetrically thick membrane specialization in the granule cell spine head. Adjacent to this gray type I synapse is the reciprocal gray type II from the granule cell spine onto the mitral secondary dendrite. Under optimal fixation, the clusters of vesicles in the spine head are elliptical in shape and slightly larger than those seen in the mitral dendrite. The presynaptic and postsynaptic membranes are symmetrical in thickness. At both synapses, the definitive synaptic cleft separating the two processes is an additional criterion useful in characterizing these dendritic circuits.

In mice injected with virus, labeled spines appeared dark with heavy deposits of the electron-dense DAB product. Nevertheless, synaptic appositions were readily identified. Multiple examples of the mitral/tufted to granule gray type I synapses were found (Fig. $6 B, C)$, defined by the presence of vesicles in the mitral/tufted cell dendrite, a clear synaptic cleft between the two membranes, and a postsynaptic density on the labeled granule cell. The reciprocal synapse from the labeled granule cell spine onto the mitral/tufted dendrite was more difficult to distinguish, in part because of the symmetry of the membrane specializations. Nevertheless, we show here an example of a reciprocal dendrodendritic synapse on the same spine head (Fig. 6D). On the right, the mitral to granule synapse can be seen, following the criteria noted above. On the left, the granule to mitral gray type II inhibitory synapse, defined 
by the presence of vesicles in the granule cell spine head (vesicles do not take up the DAB product), a distinct synaptic cleft, and a very small symmetrical postsynaptic density on the mitral cell dendrite can be seen. These data further demonstrate the integration of the adult-generated granule cells into the highly complex reciprocal dendrodendritic local circuits of the EPL. The qualitative features of the synapses described here suggest that they do not differ from established or pre-existing dendrodendritic circuits.

Our data thus far suggest that adultgenerated granule cells are not integrated into the functional synaptic circuitry of the EPL until 21 dpi. However, Carleton et al. (2003), using electrophysiological measures, and Magavi et al. (2005), using c-fos as a measure of functional activity, suggested that adult-generated granule cells are synaptically active at earlier time points. We noted above that granule cells also receive centrifugal and mitral/tufted cell axon recurrent synapses deep in the granule cell layer. These circuits are generally believed to modulate the activity of the more functionally defined dendrodendritic circuits within the EPL. Consequently, we next turned our attention to the granule cell layer and asked whether there was evidence for synapse formation on the soma or basal dendrites of adultgenerated granule cells and if so, within what temporal framework.

In the GCL, we used the postsynaptic density 95 protein (PSD-95) to determine whether there was evidence for postsynaptic specialization in the adult-generated granule cells. As shown in Figure $7 A$, PSD-95 can be detected on granule cell somata as early as $10 \mathrm{dpi}$. As a second measure, we used the GluR2/3 subunit and again found clear punctate localization around the labeled granule cell somata (Fig. 7B) and basal dendrites. In older cells, $21 \mathrm{dpi}$, the frequency or density of the GluR2/3 puncta increased notably (Fig. $7 C)$. Note at both ages puncta for GluR $2 / 3$ and PSD-95 are widely distributed in the granule cell layer indicating the postsynaptic specializations on existing unlabeled granule cells. The level of GluR2/3 expres-

sion among cells in the GCL appears variable. As seen in Figure $7 C$, although both the GFP labeled and unlabeled cells all exhibit GluR2/3 puncta, the number is inconsistent. Unlike the GluR2/3, PSD-95 expression did not seem to change over time, in either level or pattern. This suggests that some of the apparent increase in GluR2/3 may be from extrasynaptic receptors or receptors being trafficked within the cell.

To further confirm that synapses are being formed early in the GCL, we used immunoelectron microscopy at 10 dpi. Figure $8 \mathrm{~A}$ shows examples of axodendritic synapses onto unlabeled denbar, $10 \mu \mathrm{m}$.
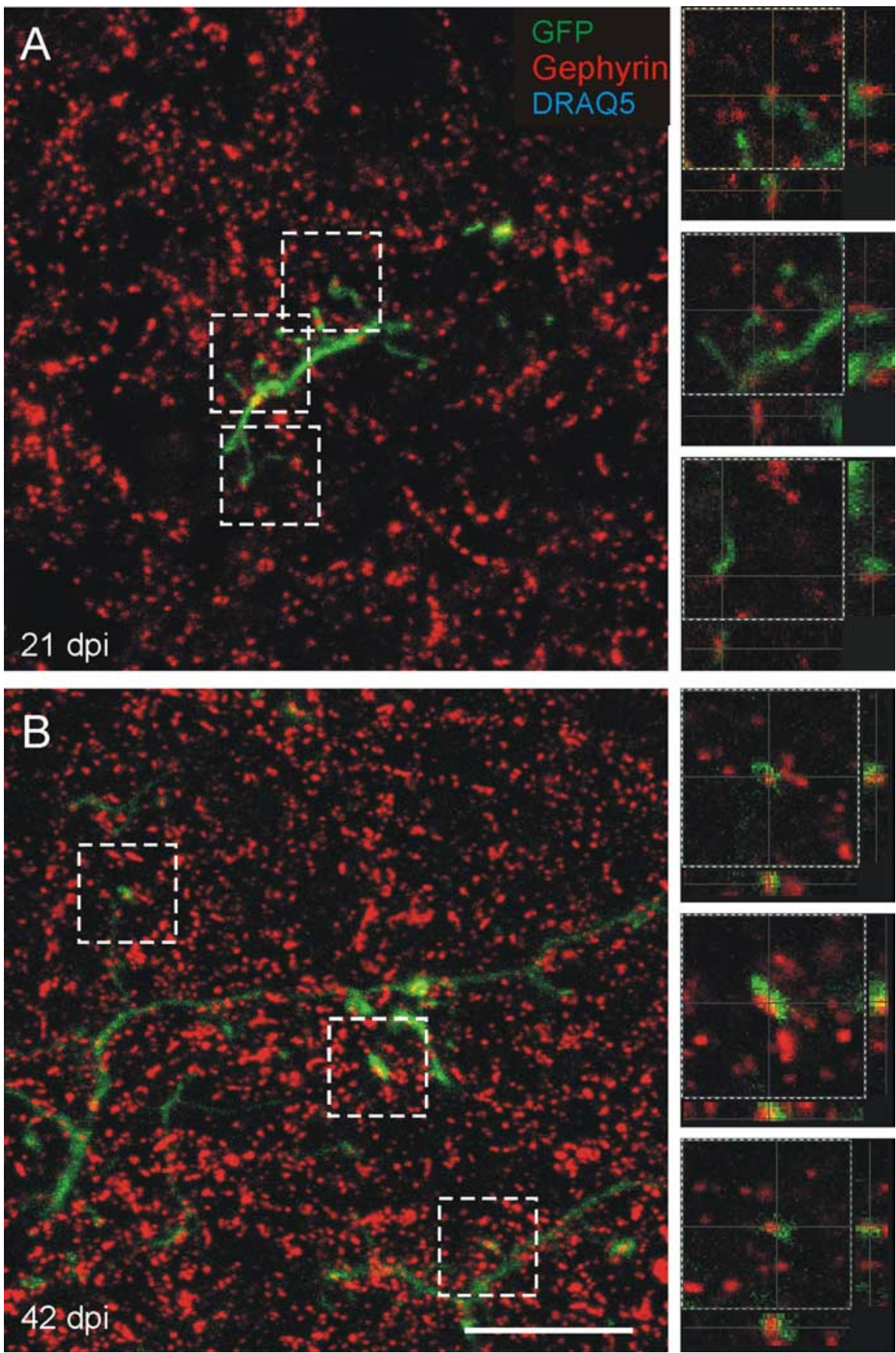

Figure 4. Gephyrin, a postsynaptic marker of GABAergic synapses, is apposed to labeled spines. $A, B$, Gephyrin (red) puncta are adjacent and apposed to spine heads on labeled cells (green) at $21 \mathrm{dpi}(\boldsymbol{A})$ and $42 \mathrm{dpi}(\boldsymbol{B})$, labeling the postsynaptic mitral/tufted dendrite receiving the synapse from the GFP-labeled spines. Images on the left are maximum projections of confocal images, and images on the right are higher-magnification single optical planes of the boxed areas on the left, showing the $z$ dimension. Scale
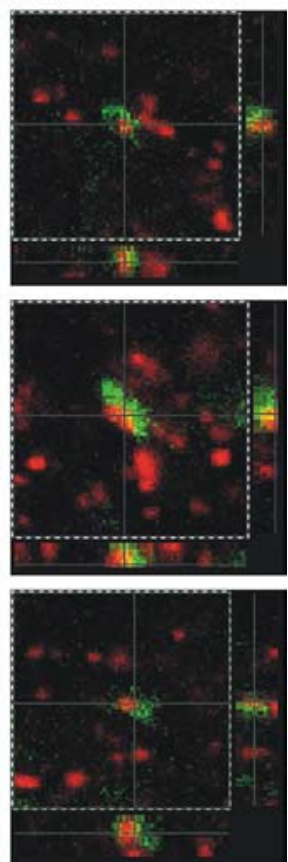

drites for reference. Clusters of vesicles in the axon terminal are accompanied by asymmetric membrane thickenings and the presence of a synaptic cleft. On the basal dendrites of labeled granule cells, both immature (Fig. $8 \mathrm{~B}$ ) and mature synapses (Fig. $8 C, D)$ can be seen. The immature synapse is defined by a small cluster of vesicles and a very small membrane thickening. The mature synapses have dense clusters of vesicles and asymmetric membrane thickenings. Interestingly, Figure $8 D$ shows a single axon terminal forming synapses onto both a labeled and an unlabeled basal dendrite. 

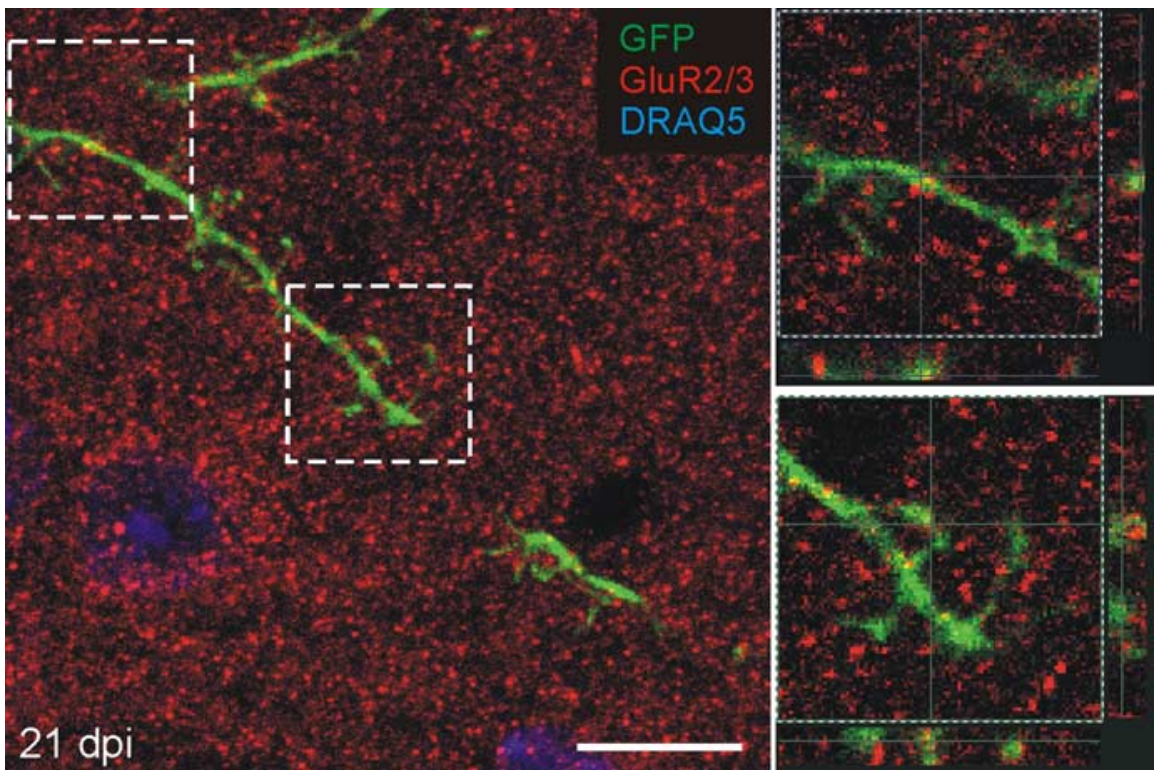

Figure 5. Adult-generated granule cells express GluR2/3, a postsynaptic marker in the EPL. GluR2/3 (red) puncta colocalize in labeled dendrites and spines in the EPL by $21 \mathrm{dpi}$. The image on the left is maximum projection of a confocal image, and images on the right are higher magnification, single optical plane, of the boxed areas on the left, showing the $z$ dimension. Scale bar, $10 \mu \mathrm{m}$.
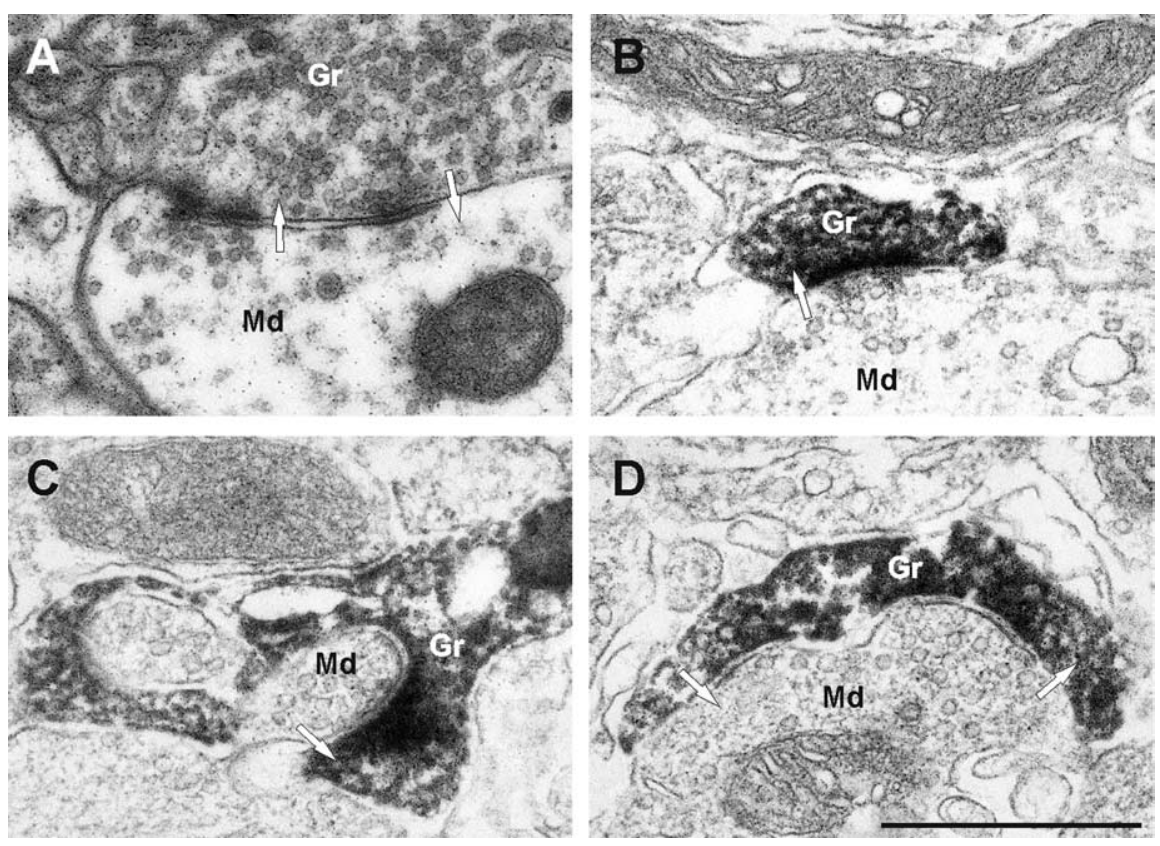

Figure 6. Electron micrographs of synapses in the EPL. A, A dendrodendritic synapse in the EPL between a mitral cell dendrite and a granule cell spine, unlabeled, for reference. The mitral to granule synapse is defined by a collection of small spherical vesicles closely apposed to the presynaptic membrane of the mitral cell secondary dendrite, and an asymmetrically thick membrane specialization in the granule cell spine head. The reciprocal granule to mitral synapse is defined by the elliptical cluster of vesicles in the spine head and symmetrical thickenings in the presynaptic and postsynaptic membranes. $\boldsymbol{B}, \boldsymbol{C}$, Examples of mitral to granule excitatory synapses on labeled spines at $42 \mathrm{dpi}$. Virally labeled cells were marked by GFP immunohistochemistry and DAB to form an electron dense product, so spines of new granule cells are darkly stained. $\boldsymbol{D}$, An example of a bidirectional dendrodendritic synapse on the same spine head. On the right, the mitral to granule synapse can be seen, and on the left, the granule to mitral inhibitory synapse. Arrows indicate the direction of the synapse. Scale bar, $1 \mu \mathrm{m}$. Md, Mitral cell dendrite; Gr, granule cell spine. collaterals of mitral or tufted cells. Given the early appearance of these synapses, it seems plausible that they direct the further maturation of adult-generated cells, possibly influencing dendritic development, spine formation, and survival.

We next asked which neurotransmitter systems showed evidence of close apposition to labeled cells. The expression of AMPA receptors on the cell body and basal dendrites (Fig. $7 B, C$ ) indicates glutamatergic inputs that may arise from intrabulbar axon collaterals of mitral and tufted cells or arrive via the anterior commissure. Another alternative is acetylcholine, which is of particular interest because prior evidence demonstrates that it plays an important role in the survival of new granule cells in the $\mathrm{OB}$ (Cooper-Kuhn et al., 2004; Mechawar et al., 2004; Kaneko et al., 2006). Cholinergic fibers originate in the nucleus of the diagonal band and terminate in the GL and GCL (Fig. 9A) (Carson, 1984; Shipley and Adamek, 1984). Using an antibody to ChAT, we looked for cholinergic fibers adjacent to labeled adultgenerated granule cells. As shown in Figure $9 B$, by 14 dpi, ChAT-labeled fibers in the GCL are in direct apposition with adult-generated granule cells. Equivalent results were obtained at $10 \mathrm{dpi}$ (data not shown). Thus, in addition to a potential role for glutamate, cholinergic fibers may form some of the first synapses with adult-generated granule cells, beginning $\sim 10 \mathrm{~d}$, allowing them to influence further maturation and survival.

\section{Discussion}

We report several novel findings in adultgenerated OB granule cells: (1) a sequence of synaptic integration in which centrifugal basal circuits precede apical circuits, (2) ultrastructural demonstration of reciprocal dendrodendritic synapses by the apical dendritic spines and apposed mitral/ tufted cell dendrites, and (3) a transient overproduction of apical dendritic spines that peaks from 28 to $42 \mathrm{~d}$ and decreases by $56 \mathrm{~d}$ after the period of granule cell death. We therefore propose a new model in which axodendritic synapses from centrifugal and mitral/tufted cell collateral axons form the first input to adult-generated granule cells and regulate their differentiation and maturation.
These results indicate that adult-generated cells receive synaptic input at the cell body and basal dendrites before their integration into the circuitry in the EPL. Synapses onto established granule cell somata and basal dendrites arise from centrifugal fibers from higher centers of the brain and from axon

\section{Spine density increases and then decreases}

Dendritic spine density in the EPL increases from 14 to $28 \mathrm{dpi}$, remains steady to $42 \mathrm{dpi}$, and decreases by $56 \mathrm{dpi}$. There are two possible explanations: pruning of spines and synaptic connections of cells surviving $>42 \mathrm{dpi}$, or preferential death of cells with 
high spine density, leaving a population with an overall lower density of spines. Of these the modification and refinement of surviving cells, as occurs elsewhere in the CNS with initial overproduction of spines/ synapses and subsequent pruning (Wolff and Missler, 1993; Lohof et al., 1996) is most plausible.

Spine dynamics in adult-generated $\mathrm{OB}$ granule cells differ significantly from adult-generated PG cells and dentate granule cells. PG spines mature more slowly; at $14 \mathrm{dpi}$, PGs have elaborate dendritic arbors, but immature filopodia-like processes appear only at $28 \mathrm{dpi}$, and mature pedunculated spines are not present until 42 dpi (Whitman and Greer, 2007). Synaptic protein expression in PG cells appears similarly retarded (our unpublished observations). Dendritic spines on new dentate granule cells appear at $16 \mathrm{dpi}$; spine density then increases slowly until 180 dpi (Zhao et al., 2006; Toni et al., 2007). Olfactory granule cells form spines $2 \mathrm{~d}$ earlier ( $14 \mathrm{dpi}$ ), shortly after their dendrite reaches the EPL, despite a longer migratory route. Spine density increases transiently before stabilizing, a maturational hypertrophy not shared by dentate granule cells. The differences may result from structural differences in the spines and their connections. Unlike dentate postsynaptic spines, olfactory granule cell spines mediate reciprocal dendrodendritic synapses. This added complexity may require more elaborate pruning and circuit refinement. Although PG cells also form dendrodendritic synapses, there may be differences in granule and PG cell precursors (Hack et al., 2005; Kohwi et al., 2005), and the range of synaptic partners in the glomerular layer is greater than in the EPL. Finally, OB interneurons may be differentially influenced by the microenvironment, such as early centrifugal input onto the granule cells.

\section{Evidence for synapses}

Previous studies on adult-generated granule cells did not directly address the formation of bidirectional synapses, or differences between apical and basal synapses. Electrophysiological studies established that as new cells develop a mature morphology their biophysical properties become similar to mature granule cells (Carleton et al., 2003). New PG cells respond after stimulation of the olfactory nerve (Belluzzi et al., 2003), but new granule cells have not been shown to respond to mitral cell stimulation. At $14 \mathrm{~d}$ postgeneration, granule cells express c-fos in response to odorants, which was interpreted as evidence of synaptic input from mitral cells, implicitly via the dendrodendritic synapses in the EPL (Magavi et al., 2005). There is evidence, however, that c-fos expression in granule cells is heavily influenced by centrifugal input (Sallaz and Jourdan, 1996) and therefore may reflect early inputs from centrifugal fibers rather than dendrodendritic input from mitral cells. Our data, in which we show the formation of centrifugal synapses significantly precedes synapse formation in apical dendrodendritic circuits, supports the latter conclusion.
Our data are the first to demonstrate ultrastructurally that adultgenerated granule cell spines form mature reciprocal connections with mitral/tufted cell dendrites in the EPL. We also present the first ultrastructural evidence for earlier axodendritic synapses on cell bodies and basal dendrites. These basal synapses are present before dendritic elaboration in the EPL.

\section{Spines before synapses}

Although dendritic spines are first evident at $14 \mathrm{dpi}$, our first evidence for synaptic integration, expression of synaptic markers, was not until $21 \mathrm{dpi}$. This could reflect some of the limitations of our method, including the possibility that the synaptic markers we used are particularly late markers. Although it seems unlikely, we cannot exclude the possibility that some spines present earlier than 21 dpi form synapses with "immature" synaptic machinery, or that we may have missed a rare earlier synapse. There is, however, precedent for transient appearance and morphological transitions in dendritic appendages (Toni et al., 2007). In the adult cortex, spines can transiently form without synapses, but spines persisting $4 \mathrm{~d}$ or more always receive axodendritic synapses (Knott et al., 2006). In the developing cortex, thin spines are likely to be transient, whereas thicker spines are usually persistent (Holtmaat et al., 2005, 2006). This is consistent with thin spines at $14 \mathrm{dpi}$ being asynaptic, but thickening as they form synapses and become persistent by $21 \mathrm{dpi}$. Given the increase in spine density and morphological maturation from 14 to $28 \mathrm{dpi}$, many of the 

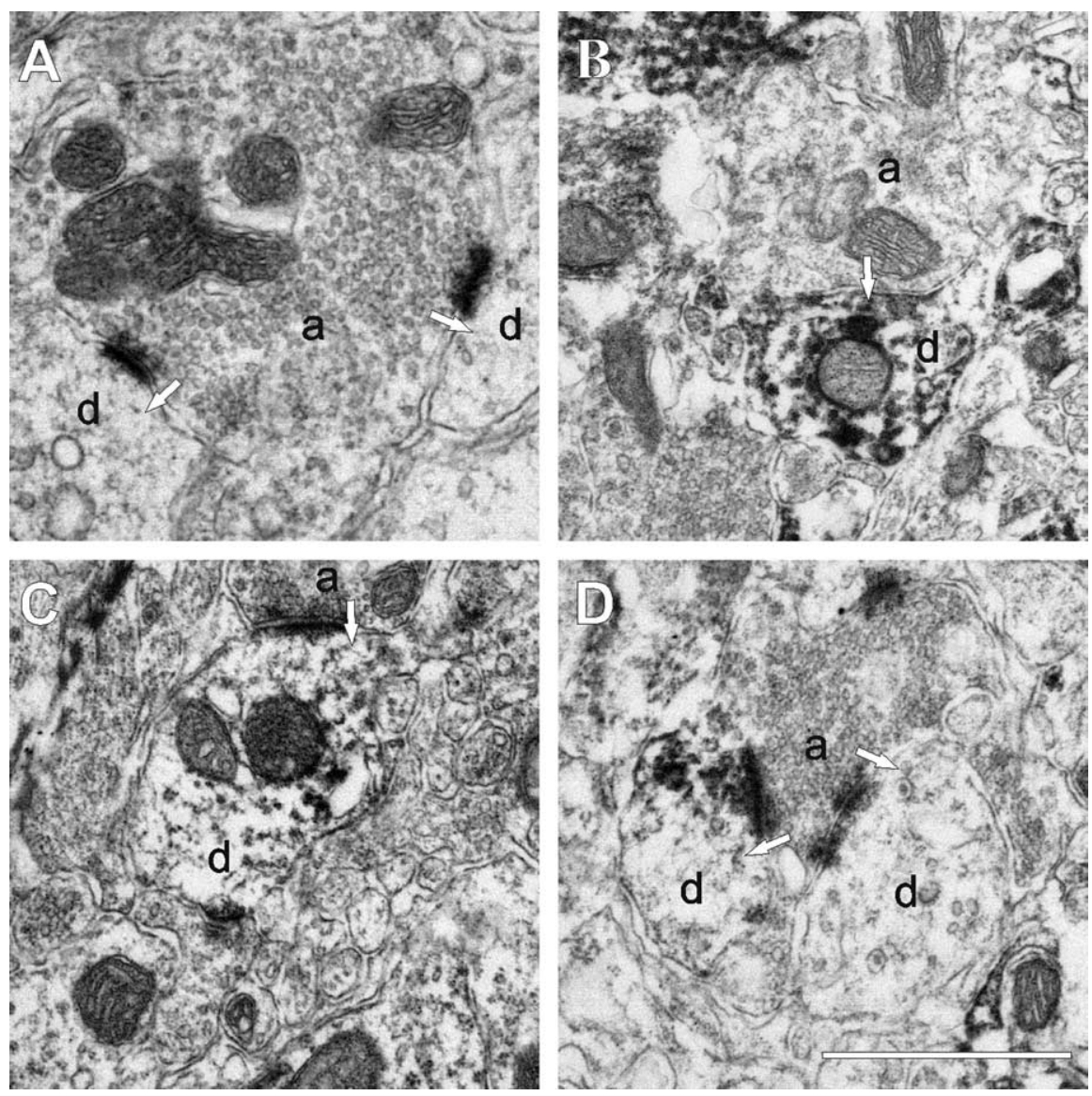

Figure 8. Electron micrographs of synapses in the $\mathrm{GCL}$ at $10 \mathrm{dpi}$. $A$, Examples of typical axodendritic synapses onto unlabeled dendrites. Clusters of vesicles in the axon terminal are accompanied by asymmetric membrane thickening and the presence of a synaptic cleft. $\boldsymbol{B}$, An immature (developing) synapse onto the basal dendrite of a labeled granule cell. The immature synapse is defined by a small cluster of vesicles and a very small membrane thickening. $C, A$ synapse that appears more morphologically mature with a well defined asymmetric postsynaptic thickening in the labeled basal dendrite. $D, A$ single axon terminal forms asymmetrical synapses onto both a labeled and an unlabeled basal dendrite. Arrows indicate direction of synapses. Scale bar, 1 $\mu \mathrm{m}$. a, Axon terminal; $d$, basal dendrite.
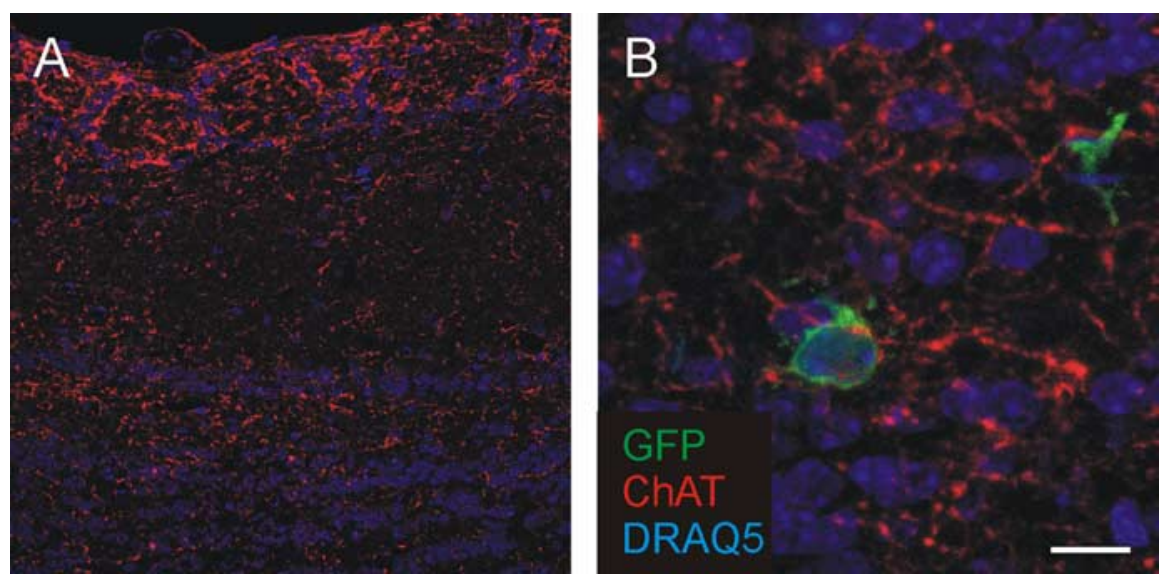

Figure 9. Cholinergic fibers contact new cells in the GCL. $A$, ChAT fibers terminate in the $\mathrm{GL}$ and GCL. $B$, An example of a cholinergic fiber contacting a new cell $14 \mathrm{dpi}$. The image is a projection of a confocal stack. Scale bar: (in $\boldsymbol{B}) \boldsymbol{A}, 32 \mu \mathrm{m} ; \boldsymbol{B}, 10 \mu \mathrm{m}$.

newly formed spines during this time must stabilize and form synapses. Our previous studies showed stable granule cell spines have a single pair of reciprocal synapses (Cameron et al., 1991; Woolf et al., 1991). The current study provides the first evidence suggesting that the stabilization of dendritic spines can include the synchronized maturation of both postsynaptic and presynaptic membrane specializations within the same spine. At later time points, $\sim 25 \%$ of dendritic appendages are filopodial, and only $\sim 65 \%$ of spines express synaptic markers, indicating that synaptic remodeling likely continues throughout the life of the cell.

\section{Centrifugal inputs}

We offer the first evidence that centrifugal fibers form the first synapses onto new granule cells, suggesting that other brain regions may influence neurogenesis, including maturation, synaptic connections, and survival. Centrifugal input to the $\mathrm{OB}$ comes from several brain regions. Fibers from the anterior commissure arise in the anterior olfactory nucleus, and piriform, periamygdaloid, and lateral entorhinal cortex. They typically innervate the OB bilaterally (Shipley and Ennis, 1996), excite granule cells, and use AMPA and NMDA receptors (Laaris et al., 2006). Modulatory inputs also arise from the nucleus of the diagonal band (cholinergic and GABAergic) (Carson, 1984; Shipley and Adamek, 1984), dorsal and median raphe (serotonergic) (McLean and Shipley, 1987), and locus ceruleus (noradrenergic) (McLean et al., 1989; McLean and Shipley, 1991).

Which centrifugal fibers are synapsing onto new granule cells and what effect might they have on further maturation? Serotonergic fibers are unlikely candidates because selective serotonin reuptake inhibitors have no effect on OB neurogenesis (Malberg et al., 2000). New granule cells express AMPA receptor subunits at synapses in the GCL, indicating that they receive glutamatergic input, either from mitral/tufted axon collaterals or the anterior commissure. Among the available candidates, cholinergic inputs are particularly attractive. Lesions of the cholinergic forebrain decrease the number of new neurons in the GCL and increase the number of apoptotic cells (Cooper-Kuhn et al., 2004). Similarly, inhibition of acetylcholinesterase increases survival of new cells in the $\mathrm{OB}$ at 4 weeks, with no effect on proliferation (Kaneko et al., 2006). Thus, increased cholinergic activity appears to increase granule cell survival. Newborn neurons in the GCL express multiple acetylcholine receptors, including the $\alpha 7, \beta 2$, $\mathrm{m} 1$, and $\mathrm{m} 4$ subunits (Kaneko et al., 2006). We demonstrate here that cholinergic fibers are closely apposed to new cells as they begin to express PSD-95 on their somata and basal dendrites, before integration of their apical dendrites into the EPL circuitry. Cholinergic input may therefore be among the earliest to new granule cells, and could exert a profound effect. 
Yamaguchi and Mori (2005) showed that sensory experience was most important for survival of new cells 14-28 d after generation, early in the period of cell death. We show that new cells have input from centrifugal fibers in the GCL by $10 \mathrm{dpi}$, but do not receive synapses in the EPL until $21 \mathrm{dpi}$. Thus, during the beginning of this "critical period" much of the input is from centrifugal axodendritic and axosomatic synapses in the GCL, indicating that activity from centrifugal fibers may be especially important in survival.

In light of these findings, we propose a new model of synaptic integration of new granule cells into the adult OB (supplemental Fig. 3, available at www.jneurosci.org as supplemental material). Ten days after generation in the SVZ, new cells can complete migration and reach the GCL, where they receive synapses from centrifugal fibers. They next extend an apical dendrite into the EPL, where it branches and extends dendritic spines, which are present for up to a week before they establish reciprocal synapses with the dendrites of mitral/tufted cells. Spine density in the EPL increases to $42 \mathrm{dpi}$, the end of the major period of cell death, before decreasing again by $56 \mathrm{dpi}$. New cells thus receive input from the circuit into which they are integrating before they are able to make any output. This, coupled with their ability to fire action potentials only late in development (Carleton et al., 2003), may prevent them from improperly influencing an already functional circuit as they attempt to integrate.

\section{References}

Alonso M, Viollet C, Gabellec MM, Meas-Yedid V, Olivo-Marin JC, Lledo PM (2006) Olfactory discrimination learning increases the survival of adult-born neurons in the olfactory bulb. J Neurosci 26:10508-10513.

Alvarez VA, Sabatini BL (2007) Anatomical and physiological plasticity of dendritic spines. Annu Rev Neurosci 30:79-97.

Belluzzi O, Benedusi M, Ackman J, LoTurco JJ (2003) Electrophysiological differentiation of new neurons in the olfactory bulb. J Neurosci 23:10411-10418.

Cameron HA, Kaliszewski CK, Greer CA (1991) Organization of mitochondria in olfactory bulb granule cell dendritic spines. Synapse 8:107-118.

Carlen M, Cassidy RM, Brismar H, Smith GA, Enquist LW, Frisen J (2002) Functional integration of adult-born neurons. Curr Biol 12:606-608.

Carleton A, Petreanu LT, Lansford R, Alvarez-Buylla A, Lledo PM (2003) Becoming a new neuron in the adult olfactory bulb. Nat Neurosci 6:507-518.

Carson KA (1984) Quantitative localization of neurons projecting to the mouse main olfactory bulb. Brain Res Bull 12:629-634.

Chesler AT, Zou DJ, Le Pichon CE, Peterlin ZA, Matthews GA, Pei X, Miller MC, Firestein S (2007) A G protein/cAMP signal cascade is required for axonal convergence into olfactory glomeruli. Proc Natl Acad Sci USA 104:1039-1044.

Cooper-Kuhn CM, Winkler J, Kuhn HG (2004) Decreased neurogenesis after cholinergic forebrain lesion in the adult rat. J Neurosci Res 77:155-165.

Ge S, Goh EL, Sailor KA, Kitabatake Y, Ming GL, Song H (2006) GABA regulates synaptic integration of newly generated neurons in the adult brain. Nature 439:589-593.

Hack MA, Saghatelyan A, de Chevigny A, Pfeifer A, Ashery-Padan R, Lledo PM, Gotz M (2005) Neuronal fate determinants of adult olfactory bulb neurogenesis. Nat Neurosci 8:865-872.

Hinds JW, Hinds PL (1976a) Synapse formation in the mouse olfactory bulb. I. Quantitative studies. J Comp Neurol 169:15-40.

Hinds JW, Hinds PL (1976b) Synapse formation in the mouse olfactory bulb. II. Morphogenesis. J Comp Neurol 169:41-61.

Holtmaat A, Wilbrecht L, Knott GW, Welker E, Svoboda K (2006) Experience-dependent and cell-type-specific spine growth in the neocortex. Nature 441:979-983.

Holtmaat AJ, Trachtenberg JT, Wilbrecht L, Shepherd GM, Zhang X, Knott GW, Svoboda K (2005) Transient and persistent dendritic spines in the neocortex in vivo. Neuron 45:279-291.
Isaacson JS, Strowbridge BW (1998) Olfactory reciprocal synapses: dendritic signaling in the CNS. Neuron 20:749-761.

Isaacson JS, Vitten $\mathrm{H}$ (2003) $\mathrm{GABA}_{\mathrm{B}}$ receptors inhibit dendrodendritic transmission in the rat olfactory bulb. J Neurosci 23:2032-2039.

Kaneko N, Okano H, Sawamoto K (2006) Role of the cholinergic system in regulating survival of newborn neurons in the adult mouse dentate gyrus and olfactory bulb. Genes Cells 11:1145-1159.

Knott GW, Holtmaat A, Wilbrecht L, Welker E, Svoboda K (2006) Spine growth precedes synapse formation in the adult neocortex in vivo. Nat Neurosci 9:1117-1124.

Kohwi M, Osumi N, Rubenstein JL, Alvarez-Buylla A (2005) Pax6 is required for making specific subpopulations of granule and periglomerular neurons in the olfactory bulb. J Neurosci 25:6997-7003.

Laaris N, Puche A, Ennis M (2007) Complementary postsynaptic activity patterns elicited in olfactory bulb by stimulation of mitral/tufted and centrifugal fiber inputs to granule cells. J Neurophysiol 97:296-306.

Lledo PM, Alonso M, Grubb MS (2006) Adult neurogenesis and functional plasticity in neuronal circuits. Nat Rev Neurosci 7:179-193.

Lohof AM, Delhaye-Bouchaud N, Mariani J (1996) Synapse elimination in the central nervous system: functional significance and cellular mechanisms. Rev Neurosci 7:85-101.

Magavi SS, Mitchell BD, Szentirmai O, Carter BS, Macklis JD (2005) Adultborn and preexisting olfactory granule neurons undergo distinct experience-dependent modifications of their olfactory responses in vivo. J Neurosci 25:10729-10739.

Malberg JE, Eisch AJ, Nestler EJ, Duman RS (2000) Chronic antidepressant treatment increases neurogenesis in adult rat hippocampus. J Neurosci 20:9104-9110.

Mates SL, Lund JS (1983) Spine formation and maturation of type 1 synapses on spiny stellate neurons in primate visual cortex. J Comp Neurol 221:91-97.

McLean JH, Shipley MT (1987) Serotonergic afferents to the rat olfactory bulb: I. Origins and laminar specificity of serotonergic inputs in the adult rat. J Neurosci 7:3016-3028.

McLean JH, Shipley MT (1991) Postnatal development of the noradrenergic projection from locus coeruleus to the olfactory bulb in the rat. J Comp Neurol 304:467-477.

McLean JH, Shipley MT, Nickell WT, Aston-Jones G, Reyher CK (1989) Chemoanatomical organization of the noradrenergic input from locus coeruleus to the olfactory bulb of the adult rat. J Comp Neurol 285:339-349.

Mechawar N, Saghatelyan A, Grailhe R, Scoriels L, Gheusi G, Gabellec MM, Lledo PM, Changeux JP (2004) Nicotinic receptors regulate the survival of newborn neurons in the adult olfactory bulb. Proc Natl Acad Sci USA 101:9822-9826.

Miller M, Peters A (1981) Maturation of rat visual cortex. II. A combined Golgi-electron microscope study of pyramidal neurons. J Comp Neurol 203:555-573.

Ming GL, Song H (2005) Adult neurogenesis in the mammalian central nervous system. Annu Rev Neurosci 28:223-250.

Panzanelli P, Perazzini AZ, Fritschy JM, Sassoe-Pognetto M (2005) Heterogeneity of gamma-aminobutyric acid type A receptors in mitral and tufted cells of the rat main olfactory bulb. J Comp Neurol 484:121-131.

Petreanu L, Alvarez-Buylla A (2002) Maturation and death of adult-born olfactory bulb granule neurons: role of olfaction. J Neurosci 22:6106-6113.

Price JL, Powell TP (1970) The synaptology of the granule cells of the olfactory bulb. J Cell Sci 7:125-155.

Rochefort C, Gheusi G, Vincent JD, Lledo PM (2002) Enriched odor exposure increases the number of newborn neurons in the adult olfactory bulb and improves odor memory. J Neurosci 22:2679-2689.

Saghatelyan A, Roux P, Migliore M, Rochefort C, Desmaisons D, Charneau P, Shepherd GM, Lledo PM (2005) Activity-dependent adjustments of the inhibitory network in the olfactory bulb following early postnatal deprivation. Neuron 46:103-116.

Sallaz M, Jourdan F (1996) Odour-induced c-fos expression in the rat olfactory bulb: involvement of centrifugal afferents. Brain Res 721:66-75.

Sassoe-Pognetto M, Fritschy JM (2000) Gephyrin, a major postsynaptic protein of GABAergic synapses. Eur J Neurosci 12:2205-2210.

Sassoe-Pognetto M, Ottersen OP (2000) Organization of ionotropic glutamate receptors at dendrodendritic synapses in the rat olfactory bulb. J Neurosci 20:2192-2201. 
Schnell SA, Staines WA, Wessendorf MW (1999) Reduction of lipofuscinlike autofluorescence in fluorescently labeled tissue. J Histochem Cytochem 47:719-730.

Shepherd GM, Chen WR, Greer CA (2004) Olfactory bulb. In: Synaptic organization of the brain, Ed 5 (Shepherd GM, ed), pp 165-216. Oxford: Oxford UP.

Shipley MT, Adamek GD (1984) The connections of the mouse olfactory bulb: a study using orthograde and retrograde transport of wheat germ agglutinin conjugated to horseradish peroxidase. Brain Res Bull 12:669-688.

Shipley MT, Ennis M (1996) Functional organization of olfactory system. J Neurobiol 30:123-176.

tom Dieck S, Sanmarti-Vila L, Langnaese K, Richter K, Kindler S, Soyke A, Wex H, Smalla KH, Kampf U, Franzer JT, Stumm M, Garner CC, Gundelfinger ED (1998) Bassoon, a novel zinc-finger CAG/glutaminerepeat protein selectively localized at the active zone of presynaptic nerve terminals. J Cell Biol 142:499-509.

Toni N, Teng EM, Bushong EA, Aimone JB, Zhao C, Consiglio A, Van Praag
H, Martone ME, Ellisman MH, Gage FH (2007) Synapse formation on neurons born in the adult hippocampus. Nat Neurosci 10:727-734.

Whitman MC, Greer CA (2007) Adult-generated neurons exhibit diverse developmental fates. Dev Neurobiol 67:1079-1093.

Wolff JR, Missler M (1993) Synaptic remodelling and elimination as integral processes of synaptogenesis. APMIS [Suppl] 40:9-23.

Woolf TB, Shepherd GM, Greer CA (1991) Serial reconstructions of granule cell spines in the mammalian olfactory bulb. Synapse 7:181-192.

Yamaguchi M, Mori K (2005) Critical period for sensory experiencedependent survival of newly generated granule cells in the adult mouse olfactory bulb. Proc Natl Acad Sci USA 102:9697-9702.

Zhang J, Diamond JS (2006) Distinct perisynaptic and synaptic localization of NMDA and AMPA receptors on ganglion cells in rat retina. J Comp Neurol 498:810-820.

Zhao C, Teng EM, Summers Jr RG, Ming GL, Gage FH (2006) Distinct morphological stages of dentate granule neuron maturation in the adult mouse hippocampus. J Neurosci 26:3-11. 